Florin Bogdan MATEI, PhD Candidate

E-mail: florin.matei@stud.ase.ro

Department of Statistics and Econometrics

The Bucharest University of Economic Studies

Professor Cristina BOBOC, PhD

E-mail: cristina.boboc@csie.ase.ro

Department of Statistics and Econometrics

The Bucharest University of Economic Studies

Professor Simona GHIȚĂ, PhD

E-mail: simona.ghita@csie.ase.ro

Department of Statistics and Econometrics

The Bucharest University of Economic Studies

\title{
THE RELATIONSHIP BETWEEN CORPORATE SOCIAL RESPONSIBILITY AND FINANCIAL PERFORMANCE IN ROMANIAN COMPANIES
}

\begin{abstract}
Corporate social responsibility (CSR) has been implemented in Romania by adapting the models from developed countries, but also by creating new models that enhance the image and the reputation of the companies, improve the organizational culture and have an overall positive effect on the financial performance of the enterprises.

This paper analyses the relationship between the CSR within the enterprises from Romania and their financial performance, by using panel data regression models. There are two methods of quantifying CSR that have been developed based on the annual reports of social actions between 2014 and 2018 and the main pillars underlying the ISO 26000 standard and that identify the CSR elements with significant impact on the financial profitability of enterprises. The results have indicated that corporate social responsibility actions carried out by companies from Romania in accordance with ISO 26000 have had a positive impact on their financial performance and a neutral impact in terms of sponsorship expenses associated with social responsibility.
\end{abstract}

Keywords: corporate social responsibility, financial performance, Romania, panel data, econometric models.

JEL Classification: M14, C23, P34

DOI: $10.24818 / 18423264 / 55.3 .21 .19$ 
Florin Bogdan Matei, Cristina Boboc, Simona Ghiță

\section{Introduction}

In the mid-20th century, social responsibility was seen as a series of philanthropic actions, but over the years, it has acquired additional targets. It has received the role of economic processes regulator or it has been associated strictly with making profit, as mentioned by Friedman (1970) in his work. By 2008, the notion of CSR had already been defined in more than 37 different ways (Dahlsrud, 2008), fact that has made us think about the lack of a consensus and the complexity of measuring it. Some of the definitions of CSR are: "employing business strategies and activities that meet the current requirements of the organization and shareholders within the limits of preserving the human and natural resources that are shall be necessary in the future" (International Institute for Sustainable Development, 1992) or "the possibility of integrating social and environmental goals in the commercial practices' (van Marrewijk, 2003).

For the business enterprise, sustainable development means adopting business strategies and activities that meet the needs of the enterprise and its stakeholders today while protecting, sustaining and enhancing the human and natural resources that will be needed in the future.

The transition from a centralized economy to a mixed economy has been particularly challenging for Romania, as it had to copy, adapt and develop models that would bring added value and stability to citizens. The standalone concept of "social responsibility" has been "imported" due to the development of multinational companies, through the act of establishing factories and subsidiaries in the country. Therefore, we cannot say that CSR has grown organically, as it has rather appeared spontaneously, quickly gaining considerable momentum over the years due to the numerous social and environmental issues caused by the low standard of living, but also due to the implementation of Western strategies.

According to the strategies adopted by companies that operate in Romania, the main benefits of implementing social responsibility policies are related to the image and reputation of the company, increasing the level of fame, as well as improving the organizational culture (Crişan-Mitra, Borza, 2015). At the other end of the spectrum, companies choose not to resort to CSR activities due to the financial, time and logistical effort, but also because they cannot obtain a competitive advantage over their main competitors, the latter being able to replicate rather quickly the employed strategies and activities.

Previous studies on Romanian Social Responsibility (Hategan et al. 2018, Vuță et al. 2019) have limited their analysis on a small number of financial actors or listed companies to prove that the actions taken in favour of the environment and society may have a positive impact on their profit. This approach can be considered a safe one and, therefore, it does not challenge the collection of data as it is already provided by the relevant organisations. By contrast, our view addresses the evaluation of two different indicator patterns and introduces the results of our new data set, with data retrieved from more than 180 social responsibility reports and balance sheets of 50 companies from 5 different activity areas. 
The Relationship between Corporate Social Responsibility and Financial Performance in Romanian Companies

According to the Romania CSR index measured by The Azores ${ }^{1}$ in 2018, the most frequently encountered pattern in terms of social responsibility in Romania is an enterprise that is involved in the processes of manufacturing and marketing soft drinks, having over 500 employees and focuses mainly on protecting the environment. Another study on corporate social responsibility in Romania, conducted by the CSR Media network ${ }^{2}$ (2019) through a survey sent to 107 companies, displays a much more detailed image of the involved companies' typology. Thus, social responsibility is seen by the majority as an opportunity to get involved in the community, as well as a way of increasing their visibility among people.

In terms of zones, at the moment there is no institution tasked with monitoring the number of social responsibility actions implemented in a region. The only available data concerns the period 2011-2016 and are based only on the reports of companies. Their analysis indicates major disparities among regions, as most CSR projects are being implemented in the Bucharest-Ilfov region, followed by the NorthWest region.

The main target of this paper is to analyse the relationship between the corporate social responsibility of enterprises from Romania and their financial performance and to identify the CSR elements that have a significant impact on the profitability of these companies. The first part of the paper conducts a comparative analysis of the main studies and results of the specialized literature in the CSR field, and based on them we shall identify the theories that will be tested. The second part of the paper presents the ways to quantify CSR on the one hand, and the financial performance of companies on the other hand, as well as the methods of analysing the relationship between the two dimensions. The third part reveals the main results of testing the devised theories regarding the influence of CSR on the financial performance of enterprises, followed by conclusions and proposals for future research in this field.

\section{Studies on the relationship between social responsibility and financial performance}

The correlation between social responsibility and financial performance is being analyzed since the 1980s, regarding the return on assets (ROA) and the return on equity (ROE) as quantitative representations of financial gain. Studies have been conducted not long after, that also introduced the enterprises' financial market capitalization. Thus, new indicators have been analyzed such as the $\mathrm{Q}$ ratio (Tobin's Q), sales or market capitalization. Brigham and Houston (2004) classified the most frequent indicators for measuring performance into factors such as liquidity, return on assets, effect of leverage, profit, as well as market capitalization

\footnotetext{
${ }^{1}$ The Azores Sustainability \& CSR Services (2018) Romania CSR Index 2018. www.theazores.ro

2 CSR Media Network (2019) CSR study - Dinamica Si Perspectiva Domeniului CSR in Romania 2019. https://www.csrmedia.ro/studii-csr/
} 
Florin Bogdan Matei, Cristina Boboc, Simona Ghiță

factors.

Previous studies, although few in number, have provided to contradictory results in relation to the relationship between CSR and enterprise performance. The topic has led to numerous debates among researchers and financial analysts and has led to the inconclusive nature of the specialty literature if this field. However, there are three possible relationships between the two concepts: positive, negative and insignificant or neutral.

Hypothesis 1: Positive relation between social responsibility and financial performance

Numerous studies confirm this hypothesis (Velte, 2017; Maqbool, Zameer, 2018). The positive impact is especially present in the case of stock market listed enterprises, due to the fact that social actions represent a piece of information that influences the decision to purchase shares, as investors are fonder of responsible companies. Kim and Kim (2014) studied social responsibility in tourism, analyzing the effect of CSR on venture capital. The result indicated an increase in the value of companies with high CSR score and a decrease in the value of those with low CSR score, the risk being reported as higher in the case of the latter.

Hypothesis 2: Negative relation between social responsibility and financial performance

The most well-known paper that dismissed the idea of positive influence between social responsibility and enterprise performance is that of Friedman (1970). He considered the concept to be "a fundamentally subversive doctrine" and mentioned the high costs of CSR strategies that could have led to a lower market competitivity of the enterprise and, thus to a decrease in profit. Wang and Sarkis (2017) proved the negative correlation between environmental activism and earnings per share in the case of 523 US companies. Elouidani and Zoubir (2015) argues that the negative impact of the enterprise's social commitment on its stock market value is noticeable especially in the case of large enterprises. Another example of a negative impact on financial performance comes from Brazil where Crisostomo et al. (2011) used the same independent variables, and in the case of CSR, the variable was calculated as the average social spending divided by the company's net sales and divided into three areas of analysis: social, environmental and corporate governance. Specifically, the negative impact on the market value of companies was noticed only for the environmental aspect and governance, while in the case of financial performance it was noticed only in the case of the relationship with the employees.

Hypothesis 3: Neutral relation between social responsibility and financial performance Most studies in the field prove that social responsibility acts independently, with no relationship with any financial result. Advocates of this hypothesis suggested that the profits generated by adopting a socially responsible approach are offset by its costs. On the one hand, McWilliams and Siegel (2000), in an attempt to adapt the economic principle of supply and demand strictly to CSR, proved that there is an equilibrium between CSR supply and demand, with the profit and costs being 
The Relationship between Corporate Social Responsibility and Financial Performance in Romanian Companies

offset. On the other hand, authors such as Ullmann (1985) argue that, in the context of a statistical model, the two variables are mutually exclusive, the relationship being insignificant, and any conclusive result is the outcome of pure chance.

Table 1 summarized the results of recent articles regarding countries from all continents. The authors came to these conclusions only by analysing several models in which both financial and control variables have been added one by one.

Table 1. Studies on the type of relationship between CSR and financial performance

\begin{tabular}{|c|c|c|c|c|}
\hline Article & Country & Relation & Financial performance & Method \\
\hline $\begin{array}{l}\text { Xie et al. } \\
(2017)\end{array}$ & $\begin{array}{l}\text { China, } \\
\text { Vietnam }\end{array}$ & $\begin{array}{l}\mathrm{N} \\
+\end{array}$ & $\begin{array}{l}\text { return on assets }(\mathrm{ROA}), \\
\text { return on equity }(\mathrm{ROE}) *\end{array}$ & $\begin{array}{l}\text { Regression } \\
\text { analysis }\end{array}$ \\
\hline $\begin{array}{l}\text { Maqbool \& } \\
\text { Zameer } \\
(2018)\end{array}$ & India & + & $\begin{array}{l}\text { ROA, ROE, net profit, } \\
\text { reward-to-variability ratio, } \\
\text { price/gain per share ratio* }\end{array}$ & Panel Analysis \\
\hline $\begin{array}{l}\text { Jun Cho et } \\
\text { al. (2019) }\end{array}$ & $\begin{array}{l}\text { South } \\
\text { Korea }\end{array}$ & $\mathrm{N}$ & $\begin{array}{l}\text { ROA, marginal rate, } \mathrm{Q} \\
\text { ratio* }\end{array}$ & Panel Analysis \\
\hline $\begin{array}{l}\text { Elouidani \& } \\
\text { Zoubir } \\
(2015)\end{array}$ & Morocco & - & $\begin{array}{l}\mathrm{ROA}, \mathrm{ROE}, \mathrm{Q} \text { ratio, } \\
\text { Marris rate* }\end{array}$ & $\begin{array}{l}\text { Regression } \\
\text { analysis }\end{array}$ \\
\hline $\begin{array}{l}\text { Siueia et al. } \\
(2019)\end{array}$ & $\begin{array}{l}\text { Sub- } \\
\text { Saharan } \\
\text { Africa }\end{array}$ & + & ROA, ROE* & Panel Analysis \\
\hline $\begin{array}{l}\text { Wang \& } \\
\text { Sarkis } \\
(2017)\end{array}$ & USA & + & ROA, Q ratio* & Panel Analysis \\
\hline $\begin{array}{l}\text { Lee et al. } \\
(2017)\end{array}$ & USA & $\mathrm{N}$ & $\begin{array}{l}\text { ROA, Q ratio, Gini } \\
\text { coefficient }\end{array}$ & $\begin{array}{l}\text { Regression } \\
\text { analysis }\end{array}$ \\
\hline $\begin{array}{l}\text { Sila \& Cek } \\
(2017)\end{array}$ & Australia & $\begin{array}{l}\mathrm{N} \\
+ \\
\end{array}$ & $\begin{array}{l}\text { Economic Performance } \\
\text { Score }\end{array}$ & $\begin{array}{l}\text { Regression } \\
\text { analysis }\end{array}$ \\
\hline $\begin{array}{l}\text { Crisostomo } \\
\text { et al. }(2011)\end{array}$ & Brazil & - & ROA, ROE, Q ratio* & $\begin{array}{l}\text { Regression } \\
\text { analysis } \\
\text { Panel Analysis } \\
\end{array}$ \\
\hline $\begin{array}{l}\text { Gabriel et } \\
\text { al. (2017) }\end{array}$ & Mexico & + & $\begin{array}{l}\text { ROA, ROE, labor } \\
\text { productivity }\end{array}$ & $\begin{array}{l}\text { Panel Analysis } \\
\text { Granger Causality }\end{array}$ \\
\hline Velte (2017) & Germany & + & ROA, Q ratio* & $\begin{array}{l}\text { Regression } \\
\text { analysis }\end{array}$ \\
\hline $\begin{array}{l}\text { Matuszak \& } \\
\text { Rozanska } \\
(2017)\end{array}$ & Poland & + & $\begin{array}{l}\text { ROA, ROE, net interest } \\
\text { margin* }\end{array}$ & Panel Analysis \\
\hline
\end{tabular}

Note: *For the models, other variables were used to mitigate the effect caused by them on the results, such as enterprise size, liquidity, leverage, solvency rate, number of years since establishment, number of employees, sector of activity, total assets, debts, degree of risk.

Legend: $N$ - neutral /insignificant relationship, + positive relationship, - negative relationship. Source: own synthesis based on the outlined articles. 
At first glance, we could say that the financial market of developed countries reacts in a positive fashion to the responsible strategy of enterprises, while conclusions cannot be drawn regarding the developing countries. The main used analysis method was the panel regression, which provides a multidimensional image of the relationship between the two studied concepts.

Table 2. Studies regarding the type of relationship between CSR and financial performance in Romania

\begin{tabular}{llll}
\hline Article & Relationship type & $\begin{array}{l}\text { Financial } \\
\text { performance }\end{array}$ & $\begin{array}{l}\text { Statistical } \\
\text { method }\end{array}$ \\
\hline $\begin{array}{l}\text { Simionescu \& } \\
\begin{array}{l}\text { Gherghina } \\
(2014)\end{array}\end{array}$ & $\begin{array}{l}\text { Random effects: }-,+ \\
\text { Fixed effects: unstable } \\
\text { results }\end{array}$ & $\begin{array}{l}\text { ROA, ROE, return on } \\
\text { sales, price/gain per } \\
\text { share ratio, price/book } \\
\text { value* }\end{array}$ & $\begin{array}{l}\text { Panel } \\
\text { Analysis }\end{array}$ \\
$\begin{array}{l}\text { Dobrea \& Dinu } \\
\text { + (between financial } \\
\text { performance and CSR } \\
\text { budget) }\end{array}$ & ROA & $\begin{array}{l}\text { Panel } \\
\text { Analysis }\end{array}$ \\
$\begin{array}{l}\text { Hategan et al. } \\
(2018)\end{array}$ & $\begin{array}{l}\text { bilateral correlation } \\
\text { - (multinational) }\end{array}$ & $\begin{array}{l}\text { assets, depreciation, } \\
\text { debts, market } \\
\text { capitalization, profit, } \\
\text { dividends** }\end{array}$ & $\begin{array}{l}\text { Panel } \\
\text { Analysis }\end{array}$ \\
\hline
\end{tabular}

Note: *The analysis used data regarding the sales, number of employees, leverage and company age for determining the control variables, **and the company size and form of ownership Source: own synthesis based on the outlined articles.

Empirical ideas and analyses regarding social responsibility in Romania have been presented very well in many studies conducted by local authors, but the influence between it and the financial aspect side has not gathered the same momentum, as few articles and theses have been generated on this topic. One of the most cited sources was Simionescu \& Gherghina's paper (2014) on the relationship between the two factors in the context of the companies listed on the Bucharest Stock Exchange. The results were different depending on the type of employed method, resulting in a negative relationship between CSR and the profitability of sales, but a positive relationship between CSR and share gain. These were the results of the panel analysis with random effects. By using the Fixed Effects Model, the positive relationship between CSR and the share gain has been reiterated.

Haţegan et al. (2018) analyzes the new challenges that businesses have to face today, namely to form an image of being sustainable besides making a profit, by using in their speech phrases such as "doing good" and "doing well". The conclusions took into account several hypotheses, and the results were valid for two of them, thus resulting in a significant correlation between the two concepts, but also in a paradox, as companies continue to do good while registering losses.

Two of the common aspects of the presented studies are the representative variables for financial performance that take into account the company's assets in the calculation formula, and the use of the regression method on simple or panel data. 
The Relationship between Corporate Social Responsibility and Financial Performance in Romanian Companies

If in most cases there was a consensus regarding the variables to be analyzed for the financial performance or market value of the company, in the case of social responsibility, things are different. Most indices are computations of authors that are based on other studies or business reports. In the rest of the cases, the data for the variables are provided by the budget allocated for CSR actions or by specialized enterprises that collect them from questionnaires, but only for very limited number of companies, mostly for those listed on the New York Stock Exchange.

Table 3. Approaches to developing the social responsibility variable

\begin{tabular}{ll}
\hline Article & Social Responsibility Variable \\
\hline Xie et al. (2017) & $\begin{array}{l}\text { Several variables representing areas of analysis, with } \\
\text { data being obtained through questionnaires }\end{array}$ \\
\hline & $\begin{array}{l}\text { CSR score = Number of CSR principles adopted by the } \\
\text { company/Total number of CSR principles (Community, } \\
\text { Environment, Working Environment and others). The } \\
\text { data for this index was taken from the sustainability } \\
\text { reports of the largest multinational companies in India, } \\
\text { and the value 1 represents the existence of the principle } \\
\text { in the ratio, while 0 represents its absence. }\end{array}$ \\
\hline $\begin{array}{l}\text { Jun Cho et al. (2019) } \\
\text { (2014), Elouidani \& Zoubir } \\
\text { (2015), Siueia et al. (2019) }\end{array}$ & $\begin{array}{l}\text { Existing Index for Measuring Social Responsibility } \\
\text { factor is present) and 0 (if it is not present) }\end{array}$ \\
\hline $\begin{array}{l}\text { Velte(2017), Wang \& Sarkis } \\
\text { (2017), Sila \& Cek (2017) }\end{array}$ & $\begin{array}{l}\text { Three variables allocated to the three central factors: } \\
\text { Environment, Society and Governance (ESG), with data } \\
\text { extracted from the databases of stock exchanges or } \\
\text { media companies }\end{array}$ \\
\hline $\begin{array}{l}\text { Crisostomo et al. (2011), } \\
\text { Dobrea \& Dinu (2012) }\end{array}$ & \begin{tabular}{l} 
CSR actions budget, personnel costs or other expenses \\
\hline Source: own synthesis based on the outlined articles
\end{tabular}
\end{tabular}

Table 3 presents the main ways of measuring and computing the representative variable of social responsibility by researching multiple studies from the field. Thus, it can be seen that there is a lack of consensus regarding the existence of a standard indicator, but there is a predominant trend to analyse company reports and form a share or sum of existing factors out of a total number that exist in a standard.

3. The type of relationship between social responsibility and financial performance in Romania

Financial dimension representative indicators

In order to test the previously presented hypotheses, the return on assets and the return on equity will be used as determinant factors of the enterprises' financial performance. The concept of social responsibility will be introduced into the 
analysis as two variables that will be calculated based on the reports published by companies, respectively based on the expenses incurred by the companies for this purpose.

The analysis presented in this paper uses panel data, the units being represented by companies and the time being represented by the annual frequency. The analysis has been made using 50 companies from 5 different areas of activity, 10 for each. They were chosen by using the ranking of companies that operate in Romania, determined by the recorded profit from 2018. The values underlying the defining indicators of the financial aspect were taken from the financial statements submitted by companies to the Ministry of Public Finance for 2014-2018 and are in accordance with the balance sheet.

The first chosen variable is the return on assets or ROA. This is obtained by dividing the obtained profit after taxes by the total value of the assets; it shows the efficiency of using the company's assets in relation to the obtained net profit:

$$
R O A=\frac{\text { Net Profit }}{\text { Total Assets }}
$$

The net profit has been obtained from the public balance sheet for each company and for each year, and the total value of assets was obtained by adding the fixed and current assets; their values have been obtained from the online platform of the Ministry of Public Finance.

The second variable calculated in order to strengthen the financial performance analysis is the return on equity or ROE, which is obtained by dividing the net profit by the equity of the enterprise. The latter was calculated by subtracting the subscribed and paid-up capital and the public or private assets from the total capital. The data have been taken from the balance sheet submitted by the companies. This is the employed method for calculating it:

$$
\text { ROE }=\frac{\text { Net Profit }}{\text { Equity }}
$$

ROE is considered by many authors to be the most appropriate indicator for measuring business performance simply because of the fact that if it is high, it implies that a small investment from the shareholders will turn a high profit, a fact that aids the process of maximizing the results.

Indicators of social responsibility measurement and control variables were introduced in the model as explanatory variables, the latter being extremely useful in stabilizing the relationship between independent and dependent variables and in eliminating unwanted effects.

The first control variable is represented by the company's field of activity: Energy and utilities, Auto, Retail, Manufacturing and distribution of daily consumer goods - FMCG and IT\&C. The second control variable is the number of employees, its values being taken from the statements published by the Ministry of Public Finance for all the years 2014-2018. The company size was included as an explanatory variable and is determined based on the turnover, total value of assets, but also on 
The Relationship between Corporate Social Responsibility and Financial Performance in Romanian Companies

the number of employees, similarly to the official distribution:

$$
\begin{aligned}
& \text { Size of Enterprise }=\text { Turnover }+A \times \text { Total assets }+B \times \\
& \times \text { Number of employees }
\end{aligned}
$$

where $\mathrm{A}$ and $\mathrm{B}$ are coefficients of equivalence with constant value, determined according to the official classification through the mediation of the maximum thresholds.

The fourth control variable is represented by the form of ownership of the company or by the majority shareholder and it is employed as a "dummy variable" with value 0 for the companies with a private majority shareholding, and value 1 for those owned by the Romanian state. The last control variable included in the model is leverage. It expresses the impact of the company's indebtedness on the return on equity. In other words, the leverage effect will increase the potential of return on an investment by using borrowed money. In this paper, the total debt of the company and its capital were used in order to determine the leverage.

\section{Determining and calculating the corporate social responsibility}

In order to provide a meaningful image of corporate social responsibility in Romania, we have developed two variables that are represent the corporate social responsibility. They are seen from two different points of view.

The first computed variable takes into account both the existence of annual reporting of social actions between 2014 and 2018, and the dimensions underlying the ISO 26000 standard. Thus, in the first phased it was checked whether for each company and for each year there was a published social responsibility report or a chapter allocated to these actions within the annual report. If there was, then the value 1 is assigned for each described social responsibility dimension that is part of one of the seven dimensions within the ISO standard. If there was none, the value 0 is assigned. The resulting values are added and then they are divided by 7 , which is the total number of standard's objectives.

$$
C S R_{I S O}=\frac{\sum_{i=1}^{n} x_{i}}{n}
$$

where $\mathrm{i}=1, \mathrm{n}$, and $\mathrm{n}$ represents the total number of dimensions in accordance with chosen standard (in our case, $\mathrm{n}=7$ ). For each $i$, the term shall $x_{i}$ be 1 if the criterion is present in part or in total and 0 otherwise.

After completing the first phase, it was found that out of the 250 possible reports only 183 were published. This represents $73.2 \%$ out of the total possible reports, a consistent percentage for an emerging state. This calculation method is similar to that employed in the study of Maqbool and Zameer (2018), but by choosing different social responsibility pillars.

The second approach to the corporate social responsibility variable uses the consolidated financial report of companies. Specifically, the CSR actions budget was taken into account or, if there was none, then the sponsorship expenses that are 
deducted by the National Agency for Fiscal Administration are considered. The choice of this calculation method is in line with the one used by Crisostomo et al. (2011) and Dobrea and Dinu (2012) who reached different conclusions, with one of them confirming the positive relationship hypothesis, and the other one disproving it.

Analysis methods of relationship between the two dimensions

The basic information about the nine variables have been summarized in the table below. At first glance, we observe that the companies included in the analysis have a low return on assets, and an average return on equity.

Table 4. Descriptive statistics of variables included in the analysis

\begin{tabular}{lllllll}
\hline Variable & Description & N & Average & $\begin{array}{l}\text { Std. } \\
\text { Deviation }\end{array}$ & Min & Max \\
\hline ROA & Return on Assets & 250 & 0.0843 & 0.1008 & -0.151 & 0.5073 \\
ROE & Return on Equity & 250 & 0.2351 & 0.3009 & 1.8439 & 1.281 \\
CSR_ISO & ISO dimension in report & 250 & 0.6337 & 0.424 & 0 & 1 \\
CSR_SP & Sponsorship expenses & 250 & 1852259 & 3643855 & 232 & 1 \\
EMP & Number of employees & 250 & 3724.55 & 3862.58 & 38 & 17866 \\
SIZE & Company size & 250 & $8.35 \mathrm{e}+09$ & $1.03 \mathrm{e}+10$ & $5.37 \mathrm{e}+08$ & $6.86 \mathrm{e}+10$ \\
LEV & Leverage & 250 & 0.554 & 0.02711 & 0.0262 & 1.7294 \\
OWNER & Type of ownership & 250 & 0.1 & 0.3006 & 0 & 1 \\
DOMAIN & Field of activity & 250 & - & - & 1 & 5 \\
\hline
\end{tabular}

Source: own processing using SAS

\section{Results of testing hypotheses regarding the impact of CSR on financial performance}

The nine variables to be analysed are: the return on total assets (ROA), the return on total equity (ROE), social responsibility calculated through method 1 (CSR_ISO), social responsibility determined by method 2 (CSR_SP), the size of company (SIZE), number of employees (EMP), leverage (LEV), field of activity (DOMAIN) and type of ownership (OWNER).

Before moving on to the analysis of regression models we shall proceed to the correlation among variables, as the first test to choose to include or eliminate related indicators, as well as choosing the effect type among statistical units.

We can observe a moderate to good correlation (between -0.75 and -0.5 or 0.5 and 0.75 ) that recommends the elimination of certain variables in the case of social responsibility through the spending method and the company size, but also in the case of the number of employees and the size of the company. There is no observed good level of association among any of the variables from this analysis, which is a omen for using the initial models in panel data analysis.

Table 5. Resulted coefficients after applying the Pearson correlation

\begin{tabular}{llllllllll}
\hline & ROA & ROE & CSR1 & CSR2 & SIZE & EMP & LEV & DOM & OWN \\
\hline ROA & 1 & & & & & & & & \\
ROE & 0.63 & 1 & & & & & & & \\
CSR1* & 0.39 & 0.21 & 1 & & & & & & \\
CSR2* & -0.01 & -0.12 & 0.13 & 1 & & & & & \\
SIZE & -0.1 & -0.19 & 0.07 & 0.6 & 1 & & & &
\end{tabular}


The Relationship between Corporate Social Responsibility and Financial Performance in Romanian Companies

\begin{tabular}{llllllllll}
\hline EMP & -0.15 & -0.27 & -0.03 & 0.48 & 0.67 & 1 & & & \\
LEV & 0.34 & 0.13 & -0.31 & -0.34 & -0.38 & -0.22 & 1 & & \\
DOM* & 0.06 & 0.17 & -0.07 & -0.12 & -0.4 & -0.18 & 0.38 & 1 & \\
OWN* & -0.03 & -0.15 & 0.02 & 0.08 & 0.2 & -0.005 & -0.49 & -0.47 & 1 \\
\hline Note: ${ }^{* C S R} 1=C S R \_I S O, C S R 2=C S R \_S P, D O M=D O M A I N, O W N=O W N E R$ & & & \\
Source: own processing using SAS
\end{tabular}

\section{Model 1: Impact of CSR as determined through the first method on ROA}

The first regression model will test the influence of CSR determined by the existence or absence of one of the seven criteria (hereinafter referred to as CSR_ISO) on the return on total assets (ROA). The number of employees, company size, domain and owner will be added in the model as explanatory variables, in order to reduce the influence of those determinants on key factors. Therefore, the model can be written according to the following form:

$R O A_{i t}=\left(\beta_{0}+v_{i}\right)+\beta_{1}$ CSR_ISO $_{i t}+\beta_{2} E M P_{i t}+\beta_{3}$ SIZE $_{i t}+\beta_{4}$ DOMAIN $_{i t}+$ $\beta_{5} O W N E R_{i t}+\varepsilon_{i t} \rightarrow$ (Fixed effects model)

$R O A_{i t}=\beta_{0}+\beta_{1} C S R_{-} I S O_{i t}+\beta_{2} E M P_{i t}+\beta_{3} S I Z E_{i t}+\beta_{4} D O M A I N_{i t}+\beta_{5} O W N E R_{i t}+$ $\left(v_{i}+\varepsilon_{i t}\right) \rightarrow$ (Random effect model)

It is important to note that the first model tests the hypothesis of a balanced panel, in which the total number of observations is $n T=250$, but also that of a short panel, where the number of entities is large and the period of time is relatively small.

The first estimating approach of model 1 is by using the Ordinary Least Squares method (hereinafter referred to as OLS) that does not take into account the two dimensions: companies and years. The resulting model is valid for a $95 \%$ guarantee probability, proven by the significant value of the Fisher test. The coefficient of determination has a value greater than $18 \%$, thus indicating an average determination of the dependent variable by the included explanatory variables. The explanatory variable that is of direct interest to us is statistically significant, along with the number of employees. The other variables are insignificant and do not have a specific influence on the return on assets. In order to explain the phenomenon, we can state that the company's profitability would increase by $9.5 \%$ for each new reported CSR pillar out of the total seven CSR pillars of the ISO 26000 standard.

The following equation is the result after applying the unidirectional fixed effects model with the estimator "Within"

$R O A_{i t}=\left(\beta_{0}+v_{i}\right)+\beta_{1} C S R_{-} I S O_{i t}+\beta_{2} E M P_{i t}+\varepsilon_{i t}$

Following the same reasoning, in the case of random effects model, the equation has the following form:

$R O A_{i t}=\beta_{0}+\beta_{1} C_{S} R_{-} I S O_{i t}+\beta_{2} E M P_{i t}+\beta_{4} D O M A I N_{i t}+\beta_{5} O W N E R_{i t}+\left(v_{i}+\varepsilon_{i t}\right)$

The fixed effect regression model provides an invalid result, as the p-value is 
greater than the $5 \%$ significance threshold. By contrast, by using the random effects approach, the results are valid and the social responsibility variable is significant. The results of this method provide the confirmation of a positive relationship between the two concepts, even if the degree of determination is lower. By comparing the OLS method and the random effects methods with the Lagrange multiplier test, we note a statistically significant value, which indicates that random effects model shall be used, as it is the most suitable one.

\section{Model 2: Impact of CSR determined by expenses method on ROA}

The second model will also consider the return on assets as a dependent variable. However, it will be considered that it is influenced by social responsibility as symbolized by sponsorship expenses accumulated by the analyzed companies each year from the chosen period. The number of employees (EMP), the size of the company (SIZE), the field of activity (DOMAIN), and the main shareholder (state or private - OWNER) were chosen as control variables. The initial model has the following form:

$$
\begin{aligned}
& R O A_{i t}=\left(\beta_{0}+v_{i}\right)+\beta_{1} C S R \_S P_{i t}+\beta_{2} E M P_{i t}+\beta_{3} S_{Z} E_{i t}+\beta_{4} D O M A I N_{i t}+ \\
& \beta_{5} O W N E R_{i t}+\varepsilon_{i t} \rightarrow(\text { Fixed effects model) } \\
& R O A_{i t}=\beta_{0}+\beta_{1} C S R \_S P_{i t}+\beta_{2} E M P_{i t}+\beta_{3} S I Z E_{i t}+\beta_{4} D O M A I N_{i t}+\beta_{5} O W N E R_{i t}+ \\
& \left(v_{i}+\varepsilon_{i t}\right) \rightarrow \text { (Random effect model) }
\end{aligned}
$$

The data on expenses of Romanian companies related to sponsorships to nongovernmental organizations have been published officially only for 2014 and 2015 . The observations with negative or null values were removed from the database, resulting in a short and unbalanced panel with $\mathrm{N}=227$.

In the case of impact of social responsibility through sponsorship expenses on the return on assets, the original form of the linear model did not meet the criteria of statistical validity for a $95 \%$ confidence level. Thus, we have chosen to use the linear logarithmic model. The adjusted model for fixed-effect version, has become:

$\ln R O A_{i t}=\left(\beta_{0}+v_{i}\right)+\beta_{1} \ln C S R \_S P_{i t}+\beta_{2} \ln E M P_{i t}+\varepsilon_{i t}$

The result of employing the method of ordinary least squares, which does not consider a separation of the temporal and individuals, was an invalid model for a $95 \%$ probability, as well as insignificant values for all exogenous variables.

The fixed effect model registered a significant value for the Fisher test, which proves the validity of the regression model in the logarithmic form. The dependent variable is explained $7.5 \%$ by the factors included in the analysis, as shown by the $\mathrm{R}^{2}$ score. Regarding the independent variables, social responsibility has an insignificant value, and the number of employees is significant. Therefore, the model would indicate towards the validation of the third hypothesis, which supports a neutral relationship between the two analysed dimensions. The random effects model also meets the validity criteria, but the Hausman test for comparing types of analysis reflects the effectiveness of fixed effects. 
The Relationship between Corporate Social Responsibility and Financial Performance in Romanian Companies

\section{Model 3: Impact of CSR determined through the first method on ROE}

The third model will analyze the influence of CSR_ISO on the return on equity, this being the other measuring indicator of financial performance. This time, in addition to the control variables assigned to the first two models, we will add the leverage to control the variables on which we focus our attention. The model will have the following equation form:

$$
\begin{aligned}
& R O E_{i t}=\left(\beta_{0}+v_{i}\right)+\beta_{1} C S R_{-} I S O_{i t}+\beta_{2} E M P_{i t}+\beta_{3} S I Z E_{i t}+\beta_{4} D O M A I N_{i t}+ \\
& \left.\beta_{5} O W N E R_{i t}+\beta_{6} L E V_{i t}+\varepsilon_{i t} \rightarrow \text { (Fixed effect model }\right) \\
& R O E_{i t}=\beta_{0}+\beta_{1} C S R_{-} I S O_{i t}+\beta_{2} E M P_{i t}+\beta_{3} S I Z E_{i t}+\beta_{4} D O M A I N_{i t}+\beta_{5} O W N E R_{i t}+ \\
& \beta_{6} L E V_{i t}+\left(v_{i}+\varepsilon_{i t}\right) \rightarrow(\text { Random effects model })
\end{aligned}
$$

Technically speaking, this case will be applied to a model on non-logarithmic data and that tests the total number of observations criterion $n T$, so that the analyzed data form a short and balanced panel.

The simple regression model, which is based on the Ordinary Least Squares method, is valid for a 5\% significance threshold, and the independent and significant factors explain the change in the return on equity in a proportion of $15,63 \%$. CSR_ISO variables and number of employees are statistically significant, which actually proves a $2.42 \%$ increase in the return on equity when the CSR value is increased by $14.28 \%$ or adding a new dimension out of the seven CSR dimensions.

The fixed effects model has three insignificant variables, as the other two are excluded, and thus it cannot be validated. The only thing left is to analyze the variables through a specific method for panel data, namely the random effects one, using the ordinary least squares method.

The result is valid according to the significant value of the Fisher test. There are only two validated explanatory variables: social responsibility, calculated by reference to the criteria of ISO 26000 standard, and the number of employees. The value of the coefficient of determination is small. This situation also occurred within the first model.

In the case of this model as well, the best results are still provided by the random effects method (Hausman test).

We can conclude that the return on equity as a representative of financial performance also depends on the social responsibility determined by taking into account the seven pillars of the standard, through the analysis of the following model.

$$
\widehat{R O E}_{i t}=0,19 C \widehat{C R} I S_{-} O_{i t}-0,00001 \widehat{E M P}_{i t}
$$




\section{Model 4: Impact of CSR determined using sponsorship expenses on ROE}

Last but not least, the fourth model will analyze the relationship between the return on equity and social responsibility calculated using the second technique. This analysis will also use the control variables from the previous model in order to mitigate the effects generated by the factors they represent. Therefore, we will have the following initial form of the model:

$$
\begin{aligned}
& R O E_{i t}=\left(\beta_{0}+v_{i}\right)+\beta_{1} C S R_{-} S P_{i t}+\beta_{2} E M P_{i t}+\beta_{3} S_{I Z E_{i t}}+\beta_{4} D_{0} O M A I N_{i t}+ \\
& \beta_{5} O W N E R_{i t}+\beta_{6} L E V_{i t}+\varepsilon_{i t} \rightarrow \text { (Fixed effects model) } \\
& R O E_{i t}=\beta_{0}+\beta_{1} C S R_{-} S P_{i t}+\beta_{2} E M P_{i t}+\beta_{3} S_{I Z E_{i t}}+\beta_{4} \text { DOMAIN }_{i t}+\beta_{5} O W N E R_{i t}+ \\
& \beta_{6} L E V_{i t}+\left(v_{i}+\varepsilon_{i t}\right) \rightarrow \text { (Random effects model) }
\end{aligned}
$$

The last model in our analysis consists of 232 observations out of the 250 possible, which makes it an unbalanced panel. Similar to the case of the second model, this original form is also not valid and must be adjusted. In addition to CSR variables and the number of employees, leverage will be added to the logarithmic equation. The first method of analyzing the regression model provides valid results, but the only significant coefficients are the ones of the number of employees and leverage. The model is also validated in the case of fixed and random effects methods for a 95\% probability, which proves the existence of stable and conclusive results.

We note that the Hausman test has a significant value, meaning that the model also accepts the fixed effects method, as the values of the social responsibility variable determined through the second method mostly generate different values over the period of time for many of the analyzed companies.

The social responsibility remains not significant in this case too, validating thus the hypothesis of a neutral relationship between the two concepts.

Table 6. Summary of estimator values resulting from the analysis

\begin{tabular}{lllll}
\hline Model & (1) ROA & (2) lnROA & (3) ROE & (4) lnROE \\
\hline Effects & Random & Fixed & Random & Fixed \\
CSR_ISO & 0.046480 & N/A & 0.192900 & N/A \\
lnCSR_SP & N/A & Insignificant & N/A & Insignificant \\
EMP* & Insignificant & 0.914324 & -0.000016 & 0.811470 \\
SIZE & N/A & N/A & N/A & N/A \\
LEV* & N/A & N/A & Insignificant & Insignificant \\
DOMAIN & Insignificant & N/A & Insignificant & N/A \\
OWNER & Insignificant & N/A & Insignificant & N/A \\
\hline \multicolumn{5}{l}{ Note: $p<0.05 ; *$ The variables in models 2 and 4 are in logarithmic form. } \\
\multicolumn{5}{l}{ Source: own processing using SAS }
\end{tabular}

In order to strengthen the efficiency and stability of the results achieved in the four models we have applied certain additional tests. Therefore, we tested the dependence between values for both dimensions (individuals and time), the stationarity of the time series and the validity of errors, by verifying the autocorrelation and heteroscedasticity. The summary of the results is presented in Table 7. 
The Relationship between Corporate Social Responsibility and Financial Performance in Romanian Companies

\begin{tabular}{|c|c|c|c|c|c|}
\hline Indicator & Test & (1) ROA & (2) InROA & (3) ROE & (4) InROE \\
\hline Dependence & LM & $\begin{array}{l}1848.8 \\
\text { (Absent) }\end{array}$ & $\begin{array}{l}1763.7 \\
\text { (Present) }\end{array}$ & $\begin{array}{l}1898.5 \\
\text { (Present) }\end{array}$ & $\begin{array}{l}1839 \\
\text { (Present) }\end{array}$ \\
\hline among grc & CD & $\begin{array}{l}3.1964 \\
\text { (Absent) }\end{array}$ & $\begin{array}{l}3.6501 \\
\text { (Present) }\end{array}$ & $\begin{array}{l}-0.9597 \\
\text { (Absent) }\end{array}$ & $\begin{array}{l}0.4829 \\
\text { (Absent) }\end{array}$ \\
\hline Stationarity & DF & $\begin{array}{l}-6.4224 \\
\text { (Stationary) }\end{array}$ & $\begin{array}{l}-6.4217 \\
\text { (Stationary) }\end{array}$ & $\begin{array}{l}-5.7789 \\
\text { (Stationary) }\end{array}$ & $\begin{array}{l}-5.8513 \\
\text { (Stationary) }\end{array}$ \\
\hline Autocorrelation & Wooldridge & $\begin{array}{l}42.713 \\
\text { (Present) }\end{array}$ & $\begin{array}{l}1.9631 \\
\text { (Absent) }\end{array}$ & $\begin{array}{l}8.2158 \\
\text { (Absent) }\end{array}$ & $\begin{array}{l}0.5401 \\
\text { (Absent) }\end{array}$ \\
\hline Heteroscedasticity & $\begin{array}{l}\text { Breusch- } \\
\text { Pagan }\end{array}$ & $\begin{array}{l}326.92 \\
\text { (Present) }\end{array}$ & $\begin{array}{l}550.63 \\
\text { (Present) }\end{array}$ & $\begin{array}{l}938.77 \\
\text { (Present) }\end{array}$ & $\begin{array}{l}660.49 \\
\text { (Present) }\end{array}$ \\
\hline
\end{tabular}

Source: own processing using SAS

On the one hand, the case in which we selected the budget allocated for social responsibility actions or sponsorship expenses as representative values for CSR has confirmed the third hypothesis (there is no dependence between accounting performance and social responsibility). This study confirms the results obtained by Xie et al.(2017), Jun Cho et al.(2019), Lee et al.(2017), Sila and Cek (2017) and other authors. On the other hand, by choosing a CSR variable determined based on dimensions that are representative for a company's sustainability, the positive relationship between social responsibility and the company's accounting performance is confirmed, thus corroborating the first hypothesis presented in this paper. Authors such as Xie et al.(2017), Maqbool \& Zameer (2018), Siueia et al.(2019) or Velte (2017) reached the same conclusion and used similar techniques in determining the corporate social responsibility factor.

Table 8. Hypotheses confirmed through the model analysis

\begin{tabular}{lllll}
\hline Model & (1) ROA & (2) InROA & (3) ROE & (4) $\ln$ ROE \\
\hline Hypothesis accepted & $1(+)$ & 3 (neutral) & $1(+)$ & 3 (neutral) \\
\hline Source: own processing using SAS & & &
\end{tabular}

\section{Conclusions}

The conclusions gathered from the results are in line with those of many authors in the field. Therefore, based on the analyzed models and taking into account the described hypotheses, two types of relationship have been confirmed: positive and neutral. The corporate social responsibility actions initiated by Romanian enterprises have a positive impact on their financial performance when the companies implement activities in accordance with sustainability standards, particularly the CSR specific standard: ISO 26000. This result confirms the studies of authors such as Siueia et al.(2019), Maqbool \& Zameer (2018), Wang \& Sarkis (2017), Gabriel et al.(2017), Velte (2017), Matuszak \&Rozanska (2017) or 
Simionescu \& Gherghina (2014). If the social responsibility is represented by sponsorship expenses, it has no influence on the profitability of the firm, as the sums allocated for charitable purposes are deducted by the Romanian State, and thus appear to have no effect. There have also been similar conclusions associated with this result, that are part of the work of Jun Cho et al.(2019), Xie et al.(2017), Lee et al.(2017) or Sila \& Cek (2017).

One of the limitations faced by this analysis was the difficulty of finding an appropriate database that was suitable for the assumptions of the research. Regarding social responsibility, the values have been determined by checking the content of the reports published by companies, which meant finding them and the report and then reading and going through it. Thus, the accuracy of the data cannot be $100 \%$ guaranteed, since the designations of the seven dimensions of the standard were often not the same as the ones used by companies in their reports. Therefore, we have resorted to finding similar features, or to classify the identified dimensions into one of the seven dimensions of the standard. Another difficulty is represented by the legislation changes on sponsorship expenses, which meant ceasing the publishing of data after 2016, but also an increase in the threshold of the amount up to which companies could deduct expenses incurred for charitable purposes. Therefore, the values from 2016 were much higher compared to the previous year, thus needing to be adjusted in order to avoid anomalies in the analysis.

In conclusion, it is difficult to determine the impact of social responsibility on the profitability of companies in Romania as there are no well-established and official indicators, and the acceptance of a hypothesis depends very much on the choice of authors in terms of variables. It also depends on the specificity of the enterprises and of the country for which the analysis is carried out. However, this can also represent benefits, by excluding CSR calculation methods that do not have a significant impact anyway and focusing the studies on the ones that provide conclusive results for finding the best way to determine this indicator.

This paper contributes to the development of research in this field by increasing the existing documentation and the level of awareness regarding the positive impact of applying standardized corporate social responsibility strategies at enterprise level.

\section{REFERENCES}

[1] Brigham, E. F., Houston, J. F. (2004), Fundamentals of Financial Management; Volume 1, Thomson/South-Western;

[2]Cho, S. J., Chung, C. Y. \& Young, J. (2019), Study on the Relationship

between CSR and Financial Performance; Sustainability 2019, 11, 343; [3]Crisostomo, V. L., de Souza Freire, F. \& de Vasconcellos, C. (2011), Corporate Social Responsibility, Firm Value and Financial Performance in Brazil; Vol. 7 No. 2 2011, pp. 295-309, Q Emerald Group Publishing Limited; 
The Relationship between Corporate Social Responsibility and Financial Performance in Romanian Companies

[4]Crișan-Mitra, C., Borza, A. (2015), Approaching CSR in Romania: An Empirical Analysis, Procedia - social and Behavioral Sciences 207 ( 2015 ) 546 552 ;

[5]Dahlsrud, A. (2008), How Corporate Social Responsibility is Defined: An Analysis of 37 Definitions, Corporate Social Responsibility and Environmental Management 15, 1-13;

[6]Dobrea, R. C., Dinu, F. A. (2012), Interdependencies between CSR Strategies and Economic Performance in Top Romanian Companies; Procedia - Social and Behavioral Sciences 62 ( 2012 ) 1208 - 1214;

[7]Elouidani, A. \& Zoubir, F. (2015), Corporate Social Responsibility and Financial Performance; African J. Accounting, Auditing and Finance, Vol. 4, No. 1, 2015, pp. 74-85;

[8]Friedman, M. (1970), The Social Responsibility of Business is to Increase its Profits; The New York Times Magazine, September 13, 1970;

[9] Gabriel, M., Lenain, P., Mehrez, M., Reynaud, J. \& Soneja, P. (2017), Doing Well by Doing Good: The Role of Mexico's Firms in Achieving Sustainable and Inclusive Growth; OECD Economics Department Working Papers No. 1383;

[10] Hategan, C.-D., Sirghi, N., Curea-Pitorac, R.-I., Hategan, V.-P. (2018), Doing Well or Doing Good: The Relationship between Corporate Social Responsibility and Profit in Romanian Companies. Sustainability 10, 1041.. doi:10.3390/su10041041;

[11] International Institute for Sustainable Development, Deloitte and Touche, Business Council for Sustainable Development (1992). Business strategy for sustainable development: Leadership and accountability for the '90s, Winnipeg Canada: IISD, 1992 82;

[12]Kim, M., Kim, Y. (2014), Corporate Social Responsibility and Shareholder Value of Restaurant Firms. International Journal of Hospitality Management, 40, 120-129;

[13]Lee C.-Y., Chang W.-C. \& Lee H.-C. (2017), An Investigation of the Effects of Corporate Social Responsibility on Corporate Reputation and Customer Loyalty - Evidence from the Taiwan Non-Life Insurance Industry; Social Responsibility Journal; Emerald Group Publishing, vol. 13(2), pages 355-369, June;

[14]Maqbool, S., Zameer, N. (2018), Corporate Social Responsibility and Financial Performance: An Empirical Analysis of Indian Banks; Future Business Journal 4 (2018) 84-93; [15]Matuszak, L. \& Rozanska, E. (2017), An Examination of the Relationship between CSR Disclosure and Financial Performance: The Case of Polish Banks; Accounting and Management Information Systems, Vol. 16, No. 4, pp. 522-533, 2017; [16]McWilliams, A. \& Siegel, D. (2000), Corporate Social Responsibility and Financial Performance; Strategic Management Journal, 21(5), 603-609; 
[17]Sila, I., Cek, K. (2017), The Impact of Environmental, Social and Governance Dimensions of Corporate Social Responsibility on Economic Performance: Australian Evidence; Procedia Computer Science 120 (2017) 797804;

[18]Simionescu, L., N. \& Gherghina, S. C. (2014), Corporate Social Responsibility and Corporate Performance: Empirical Evidence from a Panel of the Bucharest Stock Exchange Listed Companies; Management \& Marketing. Challenges for the Knowledge Society, Vol. 9 No. 4 Winter, pp. 439-458; [19]Siueia, T. T., Wang, J. \& Deladem, T. G. (2019), Corporate Social Responsibility and Financial Performance: A Comparative Study in the SubSaharan Africa Banking Sector; Journal of Cleaner Production 226 (2019) 658668 ;

[20]Van Marrewijk, M. (2003), Concepts and Definitions of CSR and Corporate Sustainability: Between Agency and Communion; Journal of Business Ethics 44(2):95-105;

[21]Ullmann, A. A. (1985), Data in Search of a Theory: A Critical Examination of the Relationships among Social Performance, Social Disclosure, and Economic Performance of US Firms; Academy of Management Review, 10(3), 540-557;

[22]Velte, P. (2017), Does ESG Performance Have an Impact on Financial Performance? Evidence from Germany; Journal of Global Responsibility 8(2); [23]Vuță, M., Cioacă, S.I., Vuță, M. and Enciu, A. (2019), An Empirical Analysis of Corporate Social Responsibility Effects on Financial Performance for Romanian Listed Companies. Amfiteatru Economic, 21(52), pp. 607-622; [24]Xie, X., Jia, Y., Meng, X. \& Li, C. (2017), Corporate Social Responsibility, Customer Satisfaction, and Financial Performance: The Moderating Effect of the Institutional Environment in Two Transition Economies; Journal of Cleaner Production 150 (2017) 26-39;

[25]Wang, Z. \& Sarkis, J. (2017), Corporate Social Responsibility Governance, Outcomes, and Financial Performance; Journal of Cleaner Production 162 (2017) 1607-1616. 